\title{
Supplementation of Zinc and Vitamin E on Apparent Digestibility of Nutrient, Carcass Traits, and Mineral Availability in Broiler Chickens
}

\author{
T. F. Rayani ${ }^{a}$, R. Mutia ${ }^{\mathrm{b} *}$, \& Sumiati ${ }^{\mathrm{b}}$ \\ aStudy Program of Nutrition and Feed Science, Faculty of Animal Science, Graduate School, \\ Bogor Agricultural University \\ ${ }^{b}$ Department of Nutrition and Feed Science, Faculty of Animal Science, Bogor Agricultural University \\ Jalan Agatis, Kampus IPB Darmaga Bogor 16680, Indonesia \\ (Received 16-08-2016; Reviewed 10-10-2016; Accepted 03-02-2017)
}

\begin{abstract}
The purpose of this study was to determine the effect of zinc $(\mathrm{Zn})$ and vitamin E supplementations on apparent nutrient digestibility, carcass traits, and mineral availability of broiler in tropical environment. The experiment was arranged in a $3 \times 3$ factorial design with 4 replications in each treatment (10 birds each). The dietary treatments were the combination of doses of zinc (A1: $0 \mathrm{ppm}$, A2: $40 \mathrm{ppm}, \mathrm{A}$ : $80 \mathrm{ppm})$ and vitamin E (B1: $0 \mathrm{ppm}, \mathrm{B} 2: 125 \mathrm{ppm}, \mathrm{B} 3: 250 \mathrm{ppm})$ supplementations. The variables observed were apparent nutrient digestibilities (apparent crude protein digestibility and apparent ether extract digestibility), carcass traits (final weight, the percentage of carcass weight, breast weight, thigh weight, wings weight, and back weight), meat bone ratio and mineral availability in the tibia (calcium [Ca], phosphorus [P], and zinc [Zn]). The results showed that apparent nutrient digestibility, carcass traits (the percentages of carcass, breast, thighs, wings, and back), meat bone ratio were not significantly influenced by the supplementation of zinc or vitamin $E$. The supplementation of $80 \mathrm{ppm}$ of $\mathrm{Zn}$ and $0 \mathrm{ppm}$ of vitamin $\mathrm{E}$ significantly $(\mathrm{P}<0.05)$ increased final weight of broiler. Supplementation of zinc alone and vitamin $E$ alone in the diet significantly $(P<0.05)$ increased calcium content of the tibia. In conclusion, supplementation of $80 \mathrm{ppm}$ of $\mathrm{Zn}$ increased calcium content compared to control, but did not affect final weight and ether-extract digestibility. Supplementation of vitamin $E$ at a dose of $125 \mathrm{ppm}$ could increase calcium content of the tibia compared to control.
\end{abstract}

Keywords: broiler, vitamin E, zinc

\section{ABSTRAK}

Tujuan penelitian ini adalah untuk mengevaluasi pengaruh suplementasi mineral zink ( $\mathrm{Zn}$ ) dan vitamin E pada kecernaan semu nutrien, kualitas karkas, dan kadar mineral pada ayam broiler yang dipelihara di lingkungan tropis. Penelitian menggunakan rancangan faktorial $3 \times 3$ dengan 4 ulangan di setiap perlakuan (10 ekor per ulangan). Perlakuan pada penelitian ini merupakan kombinasi suplementasi mineral zink (A1: 0 ppm, A2: 40 ppm, dan A3: 80 ppm) dan vitamin E (B1: 0 ppm, B2: $125 \mathrm{ppm}$, dan B3: $250 \mathrm{ppm}$ ). Variabel yang diukur adalah kecernaan nutrien semu (kecernaan protein kasar semu dan kecernaan lemak kasar semu), kualitas karkas (bobot hidup akhir, persentase karkas, dada, paha, sayap, dan punggung), rasio daging dan tulang dada, dan kadar mineral pada tulang tibia (kalsium, fosfor, dan zink). Hasil penelitian menunjukkan bahwa kecernaan nutrien semu, kualitas karkas (persentase karkas, dada, paha, sayap, dan punggung), rasio daging dan tulang dada tidak dipengaruhi secara nyata oleh penambahan mineral zink dan vitamin E pada ransum. Penambahan kombinasi $\mathrm{Zn}$ dengan dosis $80 \mathrm{ppm}$ dan vitamin $\mathrm{E}$ dengan dosis $0 \mathrm{ppm}$ berpengaruh nyata $(\mathrm{P}<0.05)$ meningkatkan bobot badan akhir ayam broiler. Penambahan mineral zink atau vitamin E secara tunggal dalam ransum berpengaruh nyata $(P<0.05)$ meningkatkan kadar kalsium dalam tulang tibia, tetapi tidak ada pengaruh penambahan kombinasi keduanya. Kesimpulan dari penelitian ini adalah penambahan mineral zink sebesar $80 \mathrm{ppm}$ meningkatkan kadar kalsium dalam tulang tibia, tetapi tidak berpengaruh terhadap bobot badan akhir dan kecernaan lemak kasar. Pemberian vitamin $\mathrm{E}$ sebanyak 125 ppm mampu meningkatkan kadar kalsium dalam tulang tibia ayam broiler dibanding kontrol.

Kata kunci: ayam broiler, mineral zink, vitamin $E$

${ }^{*}$ Corresponding author:

E-mail: rmutia.1@gmail.com 


\section{INTRODUCTION}

Ambient temperature is one of important factors that must be considered in the production of broiler chickens. Indonesia as a tropical country has a high ambient temperature that can cause heat stress in broiler. When the heat received by the body from the environment is higher than the heat loss from the body, then the body temperature will increase and cause heat stress (Sudarman et al., 2011). Heat stress affects physiological and hormonal changes and causes a decrease in feed intake. Heat stress also increases mineral excretion, and decreases concentrations of vitamin and minerals in the serum and liver (Sahin \& Krucuk, 2003). High environmental temperature is detrimental to health and dreceases immunity, and nutrient availability, which will subsequently result in low growth rates (Sahin et al., 2008; Lara \& Rostagno, 2013). The initial responses of birds suffering from heat stress are the decreased feed intake and high consumption of drinking water. High ambient temperature also decreases nutrient digestibility values. Heat stress is known to damage the barriers of digestive tract, lower blood flow by $50 \%$ in the proventriculus, gizzard, and pancreas, and by $70 \%$ in the upper duodenum and jejunum due to heat stress (Gu et al., 2012). Heat stress significanlty decreases the ash, Ca, and P content of the tibia bone and leads to the decreased bone strength (Sahin et al., 2006; HosseiniVashan et al., 2016). This factor can cause financial losses due to the decreased body weight gain, high feed convertion ratio, and mortality. Some efforts have been done to overcome those problems by adding feed additive such as antioxidant (Sahin et al., 2008; Selim et al., 2013. Habibian et al., 2014; Rusli et al., 2015). Recently, vitamin and mineral are used as antioxidants.

Vitamin E is the major antioxidant component in biological system which plays an important role in metabolism process, protecting cellular structure, and maintaining membrane stability from free radical. Vitamin E is one of the vitamins that plays an important role in the integrity of circulatory, muscular, reproductive, nervous, and immune systems of animals (Habibian et al., 2014). Supplementation of vitamin $E$ in broiler feed results in positive effects on growth performance during heat stress. Vitamin E supplementation was demonstrated to improve the quality of meat products, carcass, and cut yield, increase the activation of the immune system, and reduce the peroxidation of membrane lipids (Hashizawa et al., 2013).

Zinc $(\mathrm{Zn})$ has a major role as a component of many of metalloenzymes such as carbonic anhydrase, carboxypeptidases, and DNA polymerases (Liu et al., 2011; Liu et al., 2015; Salim et al., 2008; Salim et al., 2012). Rossi et al. (2007) reported that organic Zn (45 mg/kg, with addition of $60 \mathrm{mg} \mathrm{ZnSO} 4$ in the diets) minimized skin tearing and improved carcass appearance of broiler. Triona et al. (2007) concluded in their study that organic $\mathrm{Zn}$ (Zn-glycine) increased the proportion of breast and leg muscles, dressing percentage, and fat content in the breast and leg muscles of broiler. Deficiency of $\mathrm{Zn}$ can cause a reduction in weight gain, skeletal malformations, poor bone mineralization, and immunological dysfunctions.
Accordingly, a study on the supplementation of the broiler chickens diets with zinc and vitamin E was carried out to determine their effects on apparent nutrient digestibility, carcass quality, and mineral avaibility.

\section{MATERIALS AND METHODS}

\section{Design, Animal, and Diets}

This research used 360 male day-old chicks (Lohman strain, Japfacomfeed, Indonesia). They were raised in the cages each with the size of $1.5 \times 1.5 \mathrm{~m}$. The experiment was arranged in a $3 \times 3$ factorial design with 4 replications (10 birds each) in each treatment. The dietary treatments were 3 levels of zinc $(\mathrm{Zn})$ supplementation i.e., 0 ppm (A1), 40 ppm (A2), and 80 ppm (A3) and 3 levels of vitamin $\mathrm{E}$ (VE) supplementation i.e., 0 ppm (B1), 125 ppm (B2), and 250 ppm (B3). The diets and drinking water were provided ad-libitum. The feeding trial was conducted for $35 \mathrm{~d}$.

A comercial ration (BR 511, CP 21\%-23\%, PT. Charoend Pokphand Indonesia) was used for starter periode (1-21 d) and the finisher diets (treatments diets) consisted of a mixture of maize $(60.97 \%)$, soybean meal (26\%), fish meal (7\%), coconut oil (4\%), CaCO3 (1.08\%), $\mathrm{NaCl}(0.35 \%)$, premix $(0.50 \%)$, and DL-Methionine $(0.1 \%)$. Feed requirement of broiler was defined according to Leeson \& Summers (2008) containing the metabolizable energy of $3100 \mathrm{kcal} / \mathrm{kg}$ and $20 \%$ of crude protein. The composition of the diets and nutrient contents used in this study are shown in Table 1 . The birds were weighed and feed intake were determined on a weekly basis.

\section{Variables Measured}

Carcass traits. The variables measured in the measurement of the carcass traits were the live weight, the percentage of carcass weight, breast weight, thighs weights, wings weights, and back weight. The final live weights of the experimental chickens were the weights at the age of 35 days, a day before slaughtering, while the dressed carcass weights were obtained from chickens that were slaughtered without feather, blood, entrails, heads, and feet. Breast, thighs, wings, and back (dorsal) were weighed. The percentages of weight of breast, thighs, and back (dorsal) were calculated based on the body live weights of the birds.

Meat bone ratio of the breast. Meat bone ratio of the breast is a comparison of the abundance of meat in each unit of sternum. Meat bone ratio was obtained by separating meat and bone of the breast $(\mathrm{g})$.

Calcium, zinc, and phosphorus retentions of tibia. The right and left tibia from each bird were pressure-cooked $\left(100^{\circ} \mathrm{C}\right)$ for $20 \mathrm{~min}$. The cooked tibia were cleaned manually, and the attached muscle and cartilage were removed, and the separated tibias were washed with water and oven dried at $60^{\circ} \mathrm{C}$ for $24 \mathrm{~h}$. Preparation of tibias for dry ashing mineral analysis followed the method of AOAC Official Methods of Analysis (2005). Preparation 
of tibias for phosphorus analysis was carried out according to the method by Tausky HH and Short E (1953).

Apparent nutrient digestibility. The sampling of excreta was carried out based on the method of Farrell (1978) with a slight modification. The experimental broiler chickens were placed in metabolic cages and fasted for 24 hours. After fasting, the experimental broiler chickens were fed for $2 \mathrm{~h}$ and feed intakes were recorded. The excretas were collected over the next 24 h. Every four hours, the excretas were sprayed using a $0.01 \%$ of $\mathrm{H}_{2} \mathrm{SO}_{4}$ solution. The excretas produced were weighed and dried in an oven using a temperature of $60^{\circ} \mathrm{C}$. The measurment of the apparent nutrient digestibility was done by measuring the content of dry matter, ether extract, and crude protein in the feed and exreta. Samples for dry matter, ether extract, and crude protein analyses were prepared in accordance with the procedure of AOAC (1995).

\section{Data Analysis}

Data were then statistically analyzed with a twoway Analysis of Variance (ANOVA) by using a software SPSS application $\left(\right.$ IBM $^{\circledR} S P S S^{\circledR}$ version 21.0). Duncan Multiple Range Test (DMRT) analysis was used to determine the differences between means among the treatments (Steel \& Torrie 1995). Differences were considered significat at $\mathrm{P}<0.05$.

\section{RESULTS}

\section{Nutrient Digestibility}

The effects of supplementations of $\mathrm{Zn}$ and vitamin $\mathrm{E}$ on nutrient digestibilities are shown in Table 2. There was no significant interaction effect of $\mathrm{Zn}$ and vitamin $\mathrm{E}$ supplementations on the digestibility of crude protein and ether-extract of the diet of broiler. Furthermore supplementation of $\mathrm{Zn}$ or vitamin $\mathrm{E}$ in the diet did not affect the nutrients digestibility.

Table 1. Nutrient contents of the experimental diets (calculated)

\begin{tabular}{lcccccccccc}
\hline \multirow{2}{*}{ Nutrient contents $^{\mathrm{a}}$} & \multirow{2}{*}{ Starter $^{\mathrm{b}}$} & \multicolumn{1}{c}{ Finisher (\%) } \\
\cline { 2 - 10 } & & A1B1 & A1B2 & A1B3 & A2B1 & A2B2 & A2B3 & A3B1 & A3B2 & A3B3 \\
\hline Dry matter (\%) & 89.57 & 90.07 & 90.07 & 90.07 & 90.07 & 90.07 & 90.07 & 90.07 & 90.07 & 90.07 \\
Ash (\%) & 5.97 & 4.90 & 4.90 & 4.90 & 4.90 & 4.90 & 4.90 & 4.90 & 4.90 & 4.90 \\
Crude protein (\%) & 21.88 & 21.28 & 21.28 & 21.28 & 21.28 & 21.28 & 21.28 & 21.28 & 21.28 & 21.28 \\
Crude fiber (\%) & 2.56 & 2.08 & 2.08 & 2.08 & 2.08 & 2.08 & 2.08 & 2.08 & 2.08 & 2.08 \\
Ether extract (\%) & 6.31 & 5.35 & 5.35 & 5.35 & 5.35 & 5.35 & 5.35 & 5.35 & 5.35 & 5.35 \\
Nitrogen free extract (\%) & 52.85 & 56.46 & 56.46 & 56.46 & 56.46 & 56.46 & 56.46 & 56.46 & 56.46 & 56.46 \\
Ca (\%) & 1.83 & 1.54 & 1.54 & 1.54 & 1.54 & 1.54 & 1.54 & 1.54 & 1.54 & 1.54 \\
P (\%) & 0.46 & 0.68 & 0.68 & 0.68 & 0.68 & 0.68 & 0.68 & 0.68 & 0.68 & 0.68 \\
Gross Energy(kkal) & 4348 & 4207 & 4207 & 4207 & 4207 & 4207 & 4207 & 4207 & 4207 & 4207 \\
Vit E (ppm) & - & 0 & 125 & 250 & 0 & 125 & 250 & 0 & 125 & 250 \\
Zn (ppm) & 33.34 & 56.78 & 56.78 & 56.78 & 96.78 & 96.78 & 96.78 & 136.78 & 136.78 & 136.78 \\
\hline
\end{tabular}

Note: $\mathrm{A} 1 \mathrm{~B} 1=$ basal diet +0 ppm Zn + 0 ppm VE; A1B2= basal diet + 0 ppm Zn + 125 ppm VE; A1B3= basal diet+ 0 ppm Zn +250 ppm VE; A2B1= basal diet +40 ppm Zn + 0 ppm VE; A2B2= basal diet +40 ppm Zn + 125 ppm VE; A2B3= basal diet + 40 ppm Zn + 250 ppm VE; A3B1= basal diet + 80 ppm Zn + 0 ppm VE; A3B2= basal diet + 80 ppm Zn + 125 ppm VE; A3B3= basal diet + 80 ppm Zn + 250 VE.a)Premix content (in mg/kg premix):

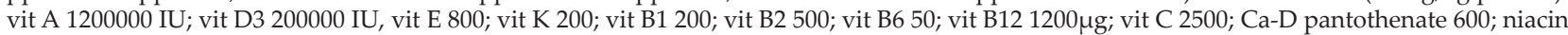
4000; choline chloride 1000 mathionine 3000; lysine 3000;manganase 12000; iron 2000; iodine 20;zinc 10000; coalt 20; copper 400; santoqium 1000; zinc bacitracin 2100, a) Laboratory of Feed Technology, Bogor Agricultural University (2015),b) Stater diet using a comercial ration c) Laboratory of Dairy Nutrition, Bogor Agricultural University (2015).

Table 2. Crude protein and ether-extract digestibility coeficients of the experimental broiler chickens fed diets supplemented with various doses of vitamin $\mathrm{E}$ and $\mathrm{Zn}$

\begin{tabular}{lccccc}
\hline \multirow{2}{*}{ Variable } & \multirow{2}{*}{$\begin{array}{c}\text { Vitamin E }(\mathrm{ppm}) \\
\text { Average }\end{array}$} \\
\cline { 3 - 5 }$(\mathrm{ppm})$ & 0 & 0 & 125 & 250 & $74.44 \pm 5.39$ \\
Crude protein & 40 & $68.57 \pm 4.92$ & $73.23 \pm 6.78$ & $74.01 \pm 7.10$ & $73.74 \pm 6.70$ \\
digestibility (\%) & 80 & $81.00 \pm 0.70$ & $77.47 \pm 1.29$ & $70.00 \pm 5.29$ & $79.79 \pm 6.84$ \\
& Average & $75.07 \pm 6.51$ & $74.23 \pm 4.53$ & $77.60 \pm 6.23$ & \\
& 0 & $86.18 \pm 1.60$ & $86.45 \pm 6.01$ & $88.19 \pm 4.96$ & $86.83 \pm 3.44$ \\
Ether extract & 40 & $87.85 \pm 4.11$ & $90.79 \pm 3.80$ & $89.27 \pm 0.12$ & $89.31 \pm 3.29$ \\
digestibility(\%) & 80 & $88.53 \pm 3.21$ & $90.95 \pm 2.41$ & $89.51 \pm 1.68$ & $89.50 \pm 2.36$ \\
& Average & $87.52 \pm 2.92$ & $89.60 \pm 4.05$ & $89.06 \pm 2.33$ & \\
\hline
\end{tabular}




\section{Carcass Traits}

There was no significant interaction effect of $\mathrm{Zn}$ and vitamin E supplementations in the diet on carcass traits
(Table 3) and meat bone ratio of experimental broiler chickens (Table 4). There were significant interactions $(\mathrm{P}<0.05)$ between $\mathrm{Zn}$ and vitamin $\mathrm{E}$ supplementation on the final body weight of broiler. Supplementation

Table 3. Carcass traits of experimental broiler chickens fed diets supplemented with various doses of vitamin $\mathrm{E}$ and $\mathrm{Zn}$

\begin{tabular}{|c|c|c|c|c|c|}
\hline \multirow{2}{*}{ Variable } & \multirow{2}{*}{$\begin{array}{c}\mathrm{Zn} \\
(\mathrm{ppm})\end{array}$} & \multicolumn{3}{|c|}{ Vitamin E (ppm) } & \multirow{2}{*}{ Average } \\
\hline & & 0 & 125 & 250 & \\
\hline \multirow[t]{3}{*}{ Final body weight (g) } & 0 & $1700.00 \pm 118.88^{\mathrm{ab}}$ & $1345.00 \pm 286.30^{c}$ & $1730.00 \pm 124.90^{\mathrm{ab}}$ & \\
\hline & 40 & $1735.00 \pm 99.83^{\mathrm{ab}}$ & $1645.00 \pm 50.00^{\mathrm{ab}}$ & $1605.00 \pm 41.23^{\mathrm{b}}$ & \\
\hline & 80 & $1825.00 \pm 138.92^{a}$ & $1565.00 \pm 59.72^{\mathrm{b}}$ & $1725.00 \pm 52.60^{\mathrm{ab}}$ & \\
\hline \multirow[t]{4}{*}{ Body weight gain (g) } & 0 & $1434.18 \pm 78.05$ & $1482.39 \pm 50.33$ & $1494.91 \pm 79.74$ & $1470.49 \pm 69.53$ \\
\hline & 40 & $1464.60 \pm 10.59$ & $1542.43 \pm 145.05$ & $1460.82 \pm 68.18$ & $1513.83 \pm 92.41$ \\
\hline & 80 & $1566.20 \pm 43.85$ & $1534.44 \pm 72.60$ & $1511.01 \pm 63.32$ & $1533.69 \pm 90.40$ \\
\hline & Average & $1566.20 \pm 98.49$ & $1518.67 \pm 97.84$ & $1511.01 \pm 63.32$ & \\
\hline \multirow[t]{4}{*}{ Carcass (\%) } & 0 & $66.01 \pm 7.78$ & $69.18 \pm 9.50$ & $68.94 \pm 4.52$ & $68.72 \pm 9.01$ \\
\hline & 40 & $66.07 \pm 3.81$ & $71.27 \pm 9.91$ & $66.89 \pm 6.09$ & $68.08 \pm 3.08$ \\
\hline & 80 & $69.85 \pm 7.17$ & $69.08 \pm 8.03$ & $65.03 \pm 4.16$ & $67.99 \pm 2.03$ \\
\hline & Average & $67.31 \pm 2.14$ & $69.84 \pm 7.29$ & $66.95 \pm 1.02$ & \\
\hline \multirow[t]{4}{*}{ Breast $(\%)$} & 0 & $33.25 \pm 2.10$ & $31.38 \pm 1.68$ & $30.10 \pm 1.35$ & $31.57 \pm 0.37$ \\
\hline & 40 & $33.57 \pm 2.18$ & $33.12 \pm 2.38$ & $31.53 \pm 2.88$ & $32.74 \pm 0.36$ \\
\hline & 80 & $34.38 \pm 0.33$ & $33.18 \pm 2.08$ & $32.24 \pm 1.79$ & $33.26 \pm 0.93$ \\
\hline & Average & $33.73 \pm 1.04$ & $32.56 \pm 0.36$ & $32.62 \pm 0.79$ & \\
\hline \multirow[t]{5}{*}{ Thigh (\%) } & 0 & $30.27 \pm 1.06$ & $33.07 \pm 2.86$ & $31.45 \pm 1.78$ & $31.60 \pm 0.91$ \\
\hline & 40 & $30.04 \pm 1.80$ & $29.88 \pm 1.85$ & $29.29 \pm 1.95$ & $29.73 \pm 0.08$ \\
\hline & 80 & $30.72 \pm 1.88$ & $30.90 \pm 1.42$ & $30.89 \pm 0.70$ & $30.84 \pm 0.59$ \\
\hline & Average & $30.34 \pm 0.46$ & $31.28 \pm 0.74$ & $30.54 \pm 0.68$ & \\
\hline & 0 & $12.13 \pm 1.93$ & $12.99 \pm 1.67$ & $12.30 \pm 1.01$ & $12.47 \pm 0.48$ \\
\hline \multirow[t]{3}{*}{ Wings (\%) } & 40 & $11.23 \pm 0.51$ & $11.03 \pm 1.32$ & $11.33 \pm 0.67$ & $11.20 \pm 0.43$ \\
\hline & 80 & $11.24 \pm 0.88$ & $11.90 \pm 0.39$ & $12.03 \pm 0.61$ & $11.72 \pm 0.25$ \\
\hline & Average & $11.53 \pm 0.74$ & $11.97 \pm 0.67$ & $11.89 \pm 0.21$ & \\
\hline \multirow[t]{4}{*}{ Back (\%) } & 0 & $19.66 \pm 2.17$ & $20.42 \pm 1.75$ & $22.15 \pm 1.40$ & $20.75 \pm 0.39$ \\
\hline & 40 & $19.64 \pm 1.23$ & $21.27 \pm 0.96$ & $19.96 \pm 1.24$ & $20.29 \pm 0.16$ \\
\hline & 80 & $20.24 \pm 1.35$ & $20.99 \pm 1.78$ & $19.86 \pm 1.76$ & $20.37 \pm 0.24$ \\
\hline & Average & $19.85 \pm 0.51$ & $20.90 \pm 0.46$ & $20.66 \pm 0.26$ & \\
\hline
\end{tabular}

Note: Means in the same column/raw with different superscripts differ significantly $(\mathrm{P}<0.05)$.

Table 4. Meat bone ratio (MBR) of breast at the age of 35 days in experimental broiler chickens fed diets supplemented with various doses of $\mathrm{Zn}$ and vitamin $\mathrm{E}$

\begin{tabular}{|c|c|c|c|c|c|}
\hline \multirow{2}{*}{ Variable } & \multirow{2}{*}{$\begin{array}{c}\mathrm{Zn} \\
(\mathrm{ppm})\end{array}$} & \multicolumn{3}{|c|}{ Vitamin E (mg) } & \multirow{2}{*}{ Average } \\
\hline & & 0 & 125 & 250 & \\
\hline \multirow[t]{4}{*}{ Breast (g) } & 0 & $371.00 \pm 34.59$ & $335.50 \pm 72.40$ & $347.50 \pm 37.24$ & $351.33 \pm 48.08$ \\
\hline & 40 & $386.25 \pm 26.29$ & $387.00 \pm 50.51$ & $336.50 \pm 15.84$ & $369.92 \pm 30.88$ \\
\hline & 80 & $437.50 \pm 47.56$ & $359.25 \pm 55.24$ & $362.50 \pm 42.26$ & $386.42 \pm 48.35$ \\
\hline & Average & $398.25 \pm 36.15$ & $360.58 \pm 59.38$ & $348.83 \pm 31.78$ & \\
\hline \multirow[t]{4}{*}{ Meat (g) } & 0 & $281.00 \pm 36.53$ & $264.00 \pm 56.85$ & $296.00 \pm 40.82$ & $280.33 \pm 44.73$ \\
\hline & 40 & $314.25 \pm 27.29$ & $301.25 \pm 24.38$ & $265.00 \pm 19.88$ & $293.50 \pm 23.85$ \\
\hline & 80 & $351.75 \pm 34.04$ & $288.75 \pm 51.82$ & $285.50 \pm 36.61$ & $308.67 \pm 40.82$ \\
\hline & Average & $315.67 \pm 32.42$ & $284.67 \pm 44.35$ & $282.17 \pm 32.44$ & \\
\hline \multirow[t]{4}{*}{ Bone (g) } & 0 & $84.25 \pm 7.63$ & $69.25 \pm 15.41$ & $51.00 \pm 9.42$ & $68.17 \pm 10.82$ \\
\hline & 40 & $70.75 \pm 18.37$ & $83.75 \pm 25.36$ & $68.25 \pm 17.86$ & $74.25 \pm 20.53$ \\
\hline & 80 & $81.25 \pm 29.80$ & $68.00 \pm 21.46$ & $74.75 \pm 17.58$ & $74.67 \pm 22.95$ \\
\hline & Average & $78.75 \pm 18.60$ & $73.67 \pm 20.73$ & $64.67 \pm 14.95$ & \\
\hline \multirow{3}{*}{$\begin{array}{l}\text { Meat bone ratio } \\
\text { (MBR) }\end{array}$} & 0 & 3.34 & 3.81 & 5.80 & \\
\hline & 40 & 4.44 & 3.60 & 3.88 & \\
\hline & 80 & 4.33 & 4.25 & 3.82 & \\
\hline
\end{tabular}


of $\mathrm{Zn} 80 \mathrm{ppm}$ at vitamin E 0 ppm gave higher response compared to that of $125 \mathrm{ppm}$ or $250 \mathrm{ppm}$. Interactions of supplementation of Zn 0 ppm and vitamin E $125 \mathrm{ppm}$ yielded the lowest final body weight.

\section{Mineral Availability}

There was no significant interaction effect of $\mathrm{Zn}$ and vitamin E supplementations in the diet on the weights of tibia as well as the content of ash (Table 5), calcium, phosphorus and zinc of the tibia of experimental broiler chickens (Table 6). However, supplementation of zinc 40 ppm or 80 ppm significantly $(\mathrm{P}<0.05)$ increased calcium content of tibia of experimental broiler chickens. Supplementation of vitamin E 125 ppm or 250 ppm significantly increased $(\mathrm{P}<0.05)$ the calcium content of broiler chickens' tibia.

\section{DISCUSSION}

High ambient temperature can decrease feed digestibility values. Stress can cause gastrointestinal injuries (Burk-holder et al., 2008) and, studies of Liu et al. (2009) and Yu et al. (2010) found that heat stress caused damages to porcine intestinal epithelia, which included the tips of the intestinal villi, inducing epithelial cell shedding, exposing the intestinal mucosa lamina proria, as well as the shortening of villus height and crypt depth. Heat stress would damage the barrier to digestive tract, lower blood flow to the digestive tract to $50 \%$ as in the proventriculus, gizzard, and pancreas, while the rate of blood flow in the upper duodenum and jejunum decreased to $70 \%$ during heat stress $(\mathrm{Gu}$ et al., 2012). In addition, Hao et al. (2012) reported that after $10 \mathrm{~h}$ of continuous heat exposure under $36 \pm 1^{\circ} \mathrm{C}$, the amylase, lipase, and trypsin activities in the intestine of broilers significantly decreased at the age of 21 d. Supplementations of $\mathrm{Zn}$ and vitamin E somehow seemed to reduce the negative effect of the heat stress.

The treatments did not affect the crude protein and ether-extract digestibility, carcass traits, meat bone ratio, the weight of tibia and content of ash, phosphorus, zinc of tibia. However, there was interaction of supplementations of $\mathrm{Zn}$ and vitamin $\mathrm{E}$ on final body weight and calcium content in the tibia. digestibility of crude protein and ether-extract on the broiler chickens. It could be due to adequacy of $\mathrm{Zn}$ or vitamin $\mathrm{E}$ in the diet for the experimental broiler chickens.

The statistical analysis indicated that there was no significant effects of supplementation of $\mathrm{Zn}$ and vitamin

Table 5. The weight and ash contents of tibia of experimental broiler chickens fed diets sipplemented with various doses of vitmin $\mathrm{E}$ and $\mathrm{Zn}$

\begin{tabular}{lccccc}
\hline \multirow{2}{*}{ Variable } & Zn & \multicolumn{3}{c}{ Vitamin E (ppm) } & Average \\
\cline { 3 - 5 }$(\mathrm{ppm})$ & 0 & 0 & 125 & 250 & $4.01 \pm 0.37$ \\
Tibia weight & 40 & $4.27 \pm 0.35$ & $3.93 \pm 0.99$ & $3.83 \pm 0.32$ & $4.09 \pm 0.16$ \\
$(\mathrm{~g})$ & 80 & $3.93 \pm 0.49$ & $4.03 \pm 0.50$ & $3.83 \pm 0.46$ & $3.84 \pm 0.18$ \\
& Average & $4.20 \pm 0.15$ & $3.00 \pm 0.17$ & $3.60 \pm 0.17$ & $41.98 \pm 1.27$ \\
& 0 & $39.96 \pm 2.92$ & $41.58 \pm 1.69$ & $45.00 \pm 4.24$ & $41.64 \pm 1.19$ \\
Ash content & 40 & $40.84 \pm 0.51$ & $41.75 \pm 2.61$ & $42.33 \pm 0.60$ & $43.13 \pm 0.49$ \\
$(\%)$ & 80 & $44.33 \pm 2.81$ & $41.51 \pm 3.69$ & $43.56 \pm 2.88$ & \\
& Average & $41.51 \pm 1.36$ & $41.61 \pm 1.00$ & $43.63 \pm 1.84$ & \\
\hline
\end{tabular}

Table 6. Calcium, phosphorus, and zinc contents of the tibia in the experimental broiler chickens fed diets supplemented with various doses of vitamin $\mathrm{E}$ and $\mathrm{Zn}$

\begin{tabular}{|c|c|c|c|c|c|}
\hline \multirow{2}{*}{ Variable } & \multirow{2}{*}{$\mathrm{Zn}$} & \multicolumn{3}{|c|}{ Vitamin E } & \multirow{2}{*}{ Average } \\
\hline & & 0 & 125 & 250 & \\
\hline Calcium & 0 & $41.35 \pm 4.12$ & $49.66 \pm 1.84$ & $50.06 \pm 0.69$ & $47.01 \pm 1.74^{\mathrm{b}}$ \\
\hline \multirow[t]{3}{*}{ (\%) } & 40 & $48.89 \pm 0.52$ & $49.84 \pm 3.73$ & $52.48 \pm 1.11$ & $50.40 \pm 1.71^{a}$ \\
\hline & 80 & $50.30 \pm 1.54$ & $53.78 \pm 10.16$ & $51.83 \pm 1.18$ & $51.97 \pm 5.08^{a}$ \\
\hline & Average & $46.85 \pm 1.86^{b}$ & $51.09 \pm 1.69^{a}$ & $51.46 \pm 0.27^{a}$ & \\
\hline Phosphorus & 0 & $12.54 \pm 1.92$ & $13.61 \pm 0.27$ & $13.12 \pm 0.18$ & $13.09 \pm 0.98$ \\
\hline \multirow[t]{3}{*}{$(\%)$} & 40 & $13.61 \pm 0.30$ & $13.31 \pm 0.16$ & $13.14 \pm 0.21$ & $13.35 \pm 0.07$ \\
\hline & 80 & $13.14 \pm 0.26$ & $13.51 \pm 0.31$ & $13.36 \pm 0.24$ & $13.34 \pm 0.04$ \\
\hline & Average & $13.10 \pm 0.95$ & $13.47 \pm 0.08$ & $13.21 \pm 0.03$ & \\
\hline Zinc & 0 & $387.56 \pm 74.84$ & $420.27 \pm 33.12$ & $418.28 \pm 24.80$ & $395.50 \pm 30.66$ \\
\hline \multirow[t]{3}{*}{ (ppm) } & 40 & $427.42 \pm 20.33$ & $415.56 \pm 2.25$ & $375.61 \pm 48.17$ & $409.53 \pm 16.25$ \\
\hline & 80 & $371.53 \pm 23.28$ & $392.77 \pm 26.47$ & $393.91 \pm 16.29$ & $395.94 \pm 16.50$ \\
\hline & Average & $408.70 \pm 26.81$ & $406.20 \pm 23.13$ & $386.07 \pm 5.21$ & \\
\hline
\end{tabular}

Note: Means in the same column/raw with different superscripts differ significantly $(\mathrm{P}<0.05)$. 
E in combination on apparent ether-extract digestibility. However, the combination of supplementation of $\mathrm{Zn}$ and vitamin $\mathrm{E}$ tended to increase the values of apparent ether-extract digestibilities. In contrast, previous studies reported by Sahin and Krucuk (2003) stated that supplementation of $\mathrm{Zn}$ in quail diet, increased apparent nutrient digestibility. Recent study reported that the percentages of $\mathrm{Zn}$ absorption, both as inorganic and organic Zn sources in the ileum, were higher than in the duodenum and jejunum (Yu et al., 2008; Yu et al., 2010). Sahin \& Kucuk (2001) reported that the digestibilities of nutrients (dry matter, organic matter, crude protein, and ether extract) increased with the increasing levels of dietary vitamin E. The increased nutrient digestibilies was probably due to the role of $\mathrm{Zn}$ in protecting pancreatic tissues from oxidative damage (Onderci et al., 2003), so that the pancreas functioned optimally to produce the digestive enzymes that would increase the digestibility of nutrient. Onderci et al. (2003) reported that supplementation of chromium and zinc decreased the digestibilities of dry matter, crude protein, and ether extract in laying hens maintained in a low temperature environment.

Heat stress can decrease body weight gain as well as feed intake and feed conversion ratio in broiler chickens (Rozenboim et al., 2007; Star et al., 2008; QuinteiroFilho et al., 2010). Supplementation of $\mathrm{Zn}$ at a dose of 80 ppm in the diet without vitamin E supplementation significantly increased final weight of broiler chickens. Zaghari et al. (2015) reported that the increase in Zn concentration of the diet by supplementing the basal diet, (with original $\mathrm{Zn}$ concentration of $24 \mathrm{mg} / \mathrm{kg}$ ) with additional $\mathrm{Zn}$ at a dose of $30 \mathrm{mg} / \mathrm{kg}$ significantly increased the final body weights of male broiler chickens. The male broiler chickens fed diets with zinc concentrations of 60.1 and $57.4 \mathrm{mg} / \mathrm{kg}$ showed the highest final body weight. Huang et al. (2007) suggest that the optimal dietary zinc level of chicks from hatch to $21 \mathrm{~d}$ of age is $84 \mathrm{mg} / \mathrm{kg}$. In contrast, supplementation of combination of $\mathrm{Zn}$ and vitamin $\mathrm{E}$ in the diets did not affect the body weight gain of broiler chickens. Broiler chickens fed diet supplemented with $\mathrm{Zn}$ at a dose of 80 ppm without vitamin E supplementation had higher body weight gains. Many studies reported that supplementary zinc did not affect growt performance such as body weight gain, feed intake, and feed conversion ratio (Kakhki et al., 2016; Liu et al., 2011, Yang et al., 2016). In a recent study, heat stress in broilers can lead to a decreased feed intake, reduced weight, and increased feed conversion ratio (Sohail et al., 2012). Supplementation of Zn as an antioxidant has reduced the negative effects of heat stress.

Supplementation of $\mathrm{Zn}$ or vitamin $\mathrm{E}$ as well as their combinations did not significantly affect the carcass traits (the percentage weight of carcass, breast, thighs, wings, and backs). Similar results were also reported by Khaki et al. (2016) that the broiler chickens fed diet with combination of zinc and $\alpha$-tocopheryl acetate ( $\alpha$-TOA) did not show any change in the yields of carcass parts. Rossi et al. (2007) also stated that carcass yields were not influenced by the increasing levels of dietary organic Zn of the broiler chickens. The statistical analysis indicated that the supplementations of $\mathrm{Zn}$ and vitamin $\mathrm{E}$ in combination in the diets of broiler chickens did not affect breast meat, breast bone, and meat bone ratio. Zhang et al. (2012) reported that broilers raised in cronic high temperature had lower proportion of breast muscle and higher proportion of thigh muscle.

Supplementations of $\mathrm{Zn}$ and vitamin $\mathrm{E}$ in combination did not significantly affect the weight of the tibia and ash percentage of the tibia in broiler chickens at the age of 35 days. Similar results were reported by Sunder et al. (2008) who showed that supplementation of $\mathrm{Zn}$ at the level of 0 to $160 \mathrm{ppm}$ did not affect the weight of the tibia and ash content of the tibia. Vakili et al. (2013) reported that the use of $\mathrm{Zn}$ and vitamin $\mathrm{E}$ did not give a significant effect on the ash content and weight of the tibia bone. According to Sahraei et al. (2012), the supplementation of $\mathrm{Zn}$ exceeded the recommended levels by as much as 40 to $70 \mathrm{ppm}$ would not affect the levels of ash in the tibia, because the supplies of calcium and phosphorus as constituents of bone were already sufficient.

Heat stress significanlty decreases the ash, $\mathrm{Ca}$, and $\mathrm{P}$ contents of the tibia bone and leads to the decreased bone strength (Sahin et al., 2006; Hosseini-Vashan et al., 2016). Diets supplemented with a combination of $\mathrm{Zn}$ and vitamin $\mathrm{E}$ did not affect calcium content of the tibia. Supplementation of $\mathrm{Zn}$ alone from 40 to $80 \mathrm{ppm}$ significantly increased calcium content of tibia bone. The most high calcium levels (51.97\%) was found when the experimental broiler chickens were supplemented with $80 \mathrm{ppm}$ of $\mathrm{Zn}$. This result was in accordance with research conducted by Sunder et al. (2008) that zinc supplementation at a dose of 80 ppm produced a high calcium content up to $37.41 \%$. Supplementation of vitamin E alone at the levels of 125 to 250 ppm significantly increased calcium content of tibia bone. Vitamin E supplementation of the diet at a dose of 125 ppm was more applicable in increasing the calcium content of tibia as compared to that of $250 \mathrm{ppm}$, because the supplementation at the two levels did not show significant differences. Lohakare et al. (2005) showed that calcium retention was higher when vitamin $\mathrm{E}$ was added at higher levels.

Supplementation of $\mathrm{Zn}$ and vitamin E in combination did not affect the phosphorus and zinc contents of the tibia, although, a recent study showed that dietary supplementation of zinc significantly affected phosphorus contents of the tibia (Sunder et al., 2008; Vieira et al., 2013). Supplementation of zinc at a dose of $40 \mathrm{ppm}$ produced optimum levels of phosphorus by $17.59 \%$. Sunder et al. (2008) suggested that bone zinc was a functional reserve of zinc of the body and it could easily be mobilized to any urgent needs by tissues. Supplementation of vitamin $\mathrm{E}$ did not affect the phosporus and zinc content of the tibia. According to Mansoub et al. (2010), vitamin $\mathrm{E}$ and zinc are nutrients that are closely related to heat stress problems. Both of them are superoxide dismutase enzyme cofactors for superoxide anion break down into oxygen and hydrogen peroxide. This leads to the possibility that heat stress stimulate the mobilization of zinc, hence, provision of vitamin $\mathrm{E}$ in this study had no significant effect. 


\section{CONCLUSION}

Supplementation of $80 \mathrm{ppm}$ of $\mathrm{Zn}$ increased calcium content compared to control, but did not affect final weight and ether-extract digestibility. Supplementation of vitamin $\mathrm{E}$ at a dose of 125 ppm could increase calcium content of the tibia compared to control.

\section{ACKNOWLEDGEMENT}

The authors would like to thank Directorate General of Higher Education of Indonesia for supporting this research through Funding Research ProgramBOPTN (Project ID No. 595/IT3.11/PT/2015).

\section{REFERENCES}

AOAC. 2005. Official Methods of Analysis of Association of Official Analitycal Chemists. 16th ed. Assoc. Off. Anal. Chem., Arlington.

[BPS] Badan Pusat Statistik. 2015. Konsumsi rata-rata per kapita seminggu beberapa macam bahan makanan penting 2007-2014. https://www.bps.go.id/linkTabelStatis/view/ id/950 . [8 August 2016]

Burkholder, K. M, K. L. Thompson, . E. Einstein, T. J. Applegate \& J. A. Patterson. 2008. Influence of stressors on normal intestinal microbiota, intestinal morphology and susceptibility to Salmonella enteriditis colonization in broilers. Poult. Sci. 87:1734-1741. https://doi.org/10.3382/ps.2008-00107

Farrel, D. J. 1978. A nutritional evaluation of buckwheat (Fagopyrum esculentum). Anim. Feed. Sci. Technol. 3(2):95108. https://doi.org/10.1016/0377-8401(78)90038-X

Gu, X. H, Y. Hao \& X. L. Wang. 2012. Over-expression of heat shock protein and its relationship to intestine under acute heat stress in goat. Int. J. Livest. 3: 27-28.

Habibian, M, S. Ghazi , M.M. Moeini \& A. Abdolmohammadi. 2014. Effect of dietary selenium and vitamin $\mathrm{E}$ on immune response and bioligical blood parameters of broiler reared under thermoneutral or heat stress condition. Int. J. Biomet. 58(5): 741-752. https://doi.org/10.1007/s00484-013-0654-y

Hao, Y, X. H. Gu \& X. L. Wang. 2012. Overexpression of heat shock protein 70 and its relationship to intestine under acute heat stress in broilers: 1 . Intestinal structure and digestive function. Poult. Sci. 91:781-789. https://doi. org/10.3382/ps.2011-01627

Hashizawa, Y, M. Kubota, M. Kadowaki \& S. Fujimura. 2013. Effect of dietary vitamin E on broiler meat qualities, color, water-holding capacity and sher force value under heat stress condition. Anim. Sci. J. 80: 732-736. https://doi. org/10.1111/asj.12079

Hosseini-Vashan, S. J., A. Golian, \& A. Yaghobfar. 2016. Growth, immune, antioxidant, and bone responses of heat stress-expossed broilers fed diets supplemented with tomato pomace. Int. J. Biometeorol. 60:1183-1192. https:// doi.org/10.1007/s00484-015-1112-9

Huang, Y. L, L. Lu, X. G. Luo \& B. Liu. 2007. An optimal dietary zinc level of broile chicks fed a corn-soybean meal diet. Pout. Sci. 86:2582-2589. https://doi.org/10.3382/ ps.2007-00088

Khakhi, R. A. M, R. Bakhshalinejad, A. Hassanabadi, \& P. Ferket. 2016. Effect of dietary organic zinc and $\alpha$-tocopheryl acetate supplements on growth performance, meat quality, tissue minerals, and $\alpha$-tocopherol deposition in broiler chickens. Poult. Sci. pew386. https://doi.org/10.3382/ps/ pew386

Lara, L. J \& M. H. Rostagno. 2013. Impact of heat stress on poultry production. Animals. 3:356-369. https://doi. org/10.3390/ani3020356

Leeson, S \& J. D. Summers. 2008. Comercial Poultry Nutrition. 3rd ed. Department of Animal and Poultry Science, University of Guelph. University Books., Guelph.

Liu, F, J. Yin, M. Du, P. Yan, J. Xu, X. Zhu, \& J. Yu. 2009. Heatstress-induced damage to porcine small intestineal ephitelium associated with downregulation of epithelial growth factor signaling. J. Anim. Sci. 87:1941-1949. https://doi. org/10.2527/jas.2008-1624

Liu, Z, L. Lu, S. Li, Z. Zhang, L. Xi, K. Zhang, \& X. Luo. 2011. Effects of supplemental zinc source and level on growth performance, carcass traits and meat quality of broilers. Poult. Sci. 90:1782-1790. https://doi.org/10.3382/ ps.2010-01215

Liu, Z. H, L. Lu, R. L. Wang, . L. Lei, S. F. Li, L. Y. Zhang, \& X. G. Luo. 2015. Effects of supplemental zinc source and level on antioxidant ability and fat metabolism-related enzymes of broilers. Poult. Sci. 94: 2686-2694. https://doi.org/10.3382/ ps/pev251

Lohakare, J. D, Y. J. Choi, J. K. Kim, J. S. Yong, Y. H. Shim, T. W. Hahn, \& B. J. Chae. 2005. Effect of dietary combinations of viramin A, E, methionine on growth performance, meat quality and immunity in comercial broilers. J. Anim. Sci. 18(4): 516-523.

Mansoub, N. H, S. C. Azar, A. A. Tehrani, A. Lotfi, \& M. K. Manesh. 2010. Influence of dietary vitamin E and zinc on performance, oxidative stability and some blood measures of broiler chickens reared under heat stress. J. Agrobiol. 27(2): 103-110.

Onderci, M, N. Sahin, K. Sahin, \& N. Kilic. 2003. The antioxidant properties of chromium and zinc: in vivo effects on digestibility, lipid peroxidation, antioxidant vitamins and some minerals under a low ambient temperature. Biol. Trace. Elem. Res. 92: 139-150. https://doi.org/10.1385/ BTER:92:2:139

Quinteiro-Filho, W. M, A. Riberio, V. Ferraz-de-Paula, M. L. Pinheiro, M. Sakai, L. R. M. Sa, A. J. P. Ferreira, \& J. Palermo-Neto. 2010. Heat stress impairs performance parameters, induces intestinal injury, and dcreases macrophage activity in broiler chickens. Poult. Sci. 89:1905-1914. https://doi.org/10.3382/ps.2010-00812

Rossi, P, F. Rutz , M. A. Anciuti, J. L. Rech, \& N. H. F. Zauk. 2007. Infuence of graded levels of organic zinc on growth performance and carcass traits of broilers.J. Appl. Poult. Res. 16: 219-225. https://doi.org/10.1093/japr/16.2.219

Rozenboim, I, E. Tajo, O. Gal-Garber, J. A. Proudman, \& Z. Uni. 2007. The effect of heat stress on ovarium function of laying hens. Poult. Sci. 86:1760-1765. https://doi. org/10.1093/ps/86.8.1760

Rusli, R. K, K. G Wiryawan, T. Toharmat, Jakaria, \& R. Mutia. 2015. Effect of manggosteen pericarp meal and vitamin $E$ supplements on the performance, blood profiles, antioxidant enzyme and HSP 70 gene expression of laying hens in tropical environment. Int. J. Poult. Sci. 14(10):570-576. https://doi.org/10.3923/ijps.2015.570.576

Sahin, K \& O. Kucuk. 2001. Effects of vitamin E and selenium on performance, digestibility of nutrients, and carcass characteristics of Japanese quails reared under heat stress $\left(34^{\circ} \mathrm{C}\right)$. J. Anim. Physiol. a. Anim. Nutr. 85: 342-348. https:// doi.org/10.1046/j.1439-0396.2001.00340.x

Sahin, K \& O. Kucuk. 2003. Heat stress and dietary vitamin supplementation of poultry diets. Nutr. Abstr. Rev. Ser. B. Livest. Feeds. Feeding. 73: 41-50.

Sahin, K, M. Onderci, N. Sahin, T. A Balci, M. F Gursu, V. Juturu, \& O. Kucuk. 2006. Dietary arginine silicate inositol complex improves bone mineralization in quail. Pout. Sci. 85:486-492. https://doi.org/10.1093/ps/85.3.486 
Sahin, N, C. Orhan, M. Tuzcu, K. Sahin, \& O. Kucuk. 2008. The effect of tomato powder supplementation on performance and lipid peroxidation in quail. Poult Sci. 87:267283. https://doi.org/10.3382/ps.2007-00207

Sahrei, M, H. Janmmohamadi, A. Taghizadeh, \& S. Cheraghi. 2012. Effect of different zinc sources on tibia bone morphology and ash content of broiler chickens. Advan. Biol. Res. 6(3): 128-132.

Salim, H. M, C. Jo, \& B. Lee . D. 2008. Zinc in broiler feeding and nutrition. Avian. Bio. Res. 1: 5-18. https://doi. org $/ 10.3184 / 175815508 \times 334578$

Salim, H, H. Lee, C. Jo, S. Lee, \& B. Lee. 2012. Effect of dietary zinc proteinate supplementation on growth performance and skin and meat quality of male and female broiler chicks. Br. Poult. Sci. 53:116-124. https://doi.org/10.1080/0 0071668.2012.658757

Selim, N. A, S. F. Youssef, A. F. Abdel-Salam, \& S. A. Nada. 2013. Evaluation of some natural antioxidant sources in broiler diets: 1-effect on growth, physiological, microbiological and immunological performance of broiler chicks. Int. J. Poult. Sci. 12:561-571. https://doi.org/10.3923/ ijps.2013.561.571

Sohail, M. U, M. E. Hume, J. A. Byrd, D. J. Nisbet, A. Ijaz, A. Sohail, M. Z. Shabbir, \& H. Rehman. 2012. Effect of supplementation of prebiotic mannan-oligosaccharides and probiotic mixture on growth performance of broilers subjected to cronic heat stress. Poult. Sci. 91:2235-2240. https:// doi.org/10.3382/ps.2012-02182

Star, L. B. Kemp. I. Van den Anker, \& H. K. Parmentier. 2008. Effect of single or combined climatic and hygienic stress in four layer lines: 1. Performance. Poult. Sci. 87:1022-1030. https://doi.org/10.3382/ps.2007-00142

Steel, R. G. D \& J. H. Torrie. 1995. Prinsip dan Prosedur Statistika. Suatu pendekatan Biometrik. Terjemahan. 5th ed. Gramedia Pustaka Utama, Jakarta.

Sudarman, A, Sumiati, \& S. H. Solikhah. 2011. Performance and meat cholesterol content of broiler chickensfed Pluchea indica L. leaf meal reared under stress condition. Med. Pet. 34:64-68. https://doi.org/10.5398/medpet.2011.34.1.64

Sunder, G. S, A. K. Panda, N. C. S. Gopinath, S. V. Rama Rao, M. V. L. N. Raju, M. R. Reddy, \& K. Ch. Vijay. 2008. Effect of higher levels of zinc supplementation on performance, mineral availability and immune competence in broiler chickens. J. Appl. Poult. Res. 17: 79-85. https://doi. org/10.3382/japr.2007-00029
Taussky, H. H \& E. E. Shor. 1953. A microcolometric method for determination of inorganic phosphorus. J. Biol. Chem. 202(2): 85-675.

Troine, W, S. Kinal, \& B. Lubojemska. 2007. Effect of various forms of zinc applied in concentrate mixtures for broiler chickens on its bioavailability as well as meat composition and quality. Poult. J. Food. Nutr. Sci. 57: 577-581.

Vakili, R, A. S. Rashidi, \& S. Sobjanirad. 2010. Effects of dietary fat, vitamin $\mathrm{E}$ and zinc supplementation on tibia breaking strenght in female broilers under heat stress. Afr. J. Agric. Res. 5(23): 3151-3156.

Vieira, M. M, A. M. L. Riberio, A. M. Kessler, M. A. Kunrath, \& V. S. Ledur. 2013. Different sources of dietary zinc for broiler submitted to immunological, nutritional and environmental challange. J. Appl. Poult. Res. 22: 855-861. https://doi.org/10.3382/japr.2013-00753

Yang, W. L, Y. P. Chen, Y. F. Cheng, X. H. Li, R. Q. Zhang, C. Wen, \& Y. M. Zhou. 2016. An evaluation of zinc bearing palygorskite inclusion on the growth performance, mineral content, meat quality and atioxidant status of broilers. Poult. Sci. 95:878-885. https://doi.org/10.3382/ps/pev445

Yu, J, P. Yin, F. H. Liu, G. L. Cheng, K. J. Guo, A. Lu, X. Y. Zhu, W. L. Luan, \& J. Q. Xu. 2010. Effect of heat stress on the porcine small intestine: A morphological and gene expression study. Comp. Biochem. Physiol. A Mol. Intergr. Physiol. 156:119-128. https://doi.org/10.1016/j.cbpa.2010.01.008

Yu, Y, L. Lu, X. G. Luo, \& B. Liu. 2008. Kinetics of zinc absorption by in situ ligated intestinal loops of broilers involved in zinc transportes. Poult. Sci. 87:1146-1155.

Yu, Y, L. Lu, R. L. Wang, L. Xi, X. G. Luo, \& B. Liu. 2010. Effect of zinc source and phytate on zinc absoption by in situ ligated intestinal loops of broilers. Poult. Sci. 89:2157-2165. https://doi.org/10.3382/ps.2009-00486

Zaghari, M, M. Avazkhanllo, \& M. Ganjkhanlou. 2015. Reevaluation of male broilerzinc requirement by doseresponse trial using practical diet with added exogenus phytase. J. Agr. Sci. Tech. 17: 333-343.

Zhang, Z. Y, G. Q. Jia, J. J. Zuo, Y. Zhang, J. Lei, L. Ren, \& D. Y. Feng. 2012. Effect of constant and cyclic heat stess on muscle metabolism and meat quality of broiler breast fillet and thigh meat. Poult. Sci. 91:2931-2937. https://doi. org/10.3382/ps.2012-02255 